\title{
Leading Edge of Plant Protection for Walnuts
}

William H. Olson ${ }^{1}$ and Richard P. Buchner ${ }^{2}$

\begin{abstract}
Additional INDEX wORDS. reduced-risk pest management, integrated pest management, codling moth, walnut husk fly, walnut aphid, walnut blight, crown gall, pheromone, Trichogramma platneri, Juglans regia

Summary. English walnut (Juglans regia) producers in California compete with many insect and disease pests to produce an acceptable crop. Traditional control strategies work reasonably well for most pests. However, environmental concerns, loss of certain pesticides and new or impending regulations threaten the use of many traditional techniques for control of many of the pests. Codling moth (Cydia pomonella), walnut husk fly (Rbagoletis completa), and walnut aphid (Chromaphis juglandicola) are the major insects that affect California walnut production. Control strategies that use integrated pest management programs, beneficial insects, mating disruption, insect growth regulators, improved monitoring techniques and precise treatment timing based on the insect's life cycle are leading edge techniques currently available for insect control in walnuts. Major diseases include walnut blight (Xanthomonas campestris pv.

juglandis), crown gall (Agrobacterium tumefaciens) and crown and root rot (Phytophthora spp). Both copper resistant and copper sensitive strains of the walnut blight bacterium are best controlled with combinations of copper bactericides and maneb instead of copper materials alone. A new computer model, Xanthocast, used to forecast the need for walnut blight treatment is under evaluation. Crown gall is managed using a preplant biological control agent and a heat treatment to eradicate existing galls. Phytophthora crown and root rot is dealt with primarily by site selection, irrigation management and rootstock selection.
\end{abstract}

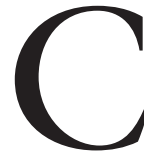

alifornia produces $99 \%$ of the walnuts grown in the United States and $38 \%$ of the world's production. About $95 \%$ of California walnuts are grown in the central valley from Tulare County in the south to Tehama County in the north. There are about 196,000 acres $(79,320 \mathrm{ha})$ of producing walnut orchards and another 28,000 acres $(11,331 \mathrm{ha})$ yet to come into production. Total annual production is near 260,000 tons $(235,935 \mathrm{t})$ with $40 \%$ of the crop being exported. The 2001 California Walnut Objective Measurement Survey Report forecasts the 2001 walnut crop to be 280,000 tons $(254,083 \mathrm{t})$ (Tippett et al., 2001). The inshell product accounts for $35 \%$ of the market. In California, 17 cultivars of english walnut are grown on three rootstocks. It cost about $\$ 700 /$ acre $(\$ 1,730 / \mathrm{ha})$ in cultural cost, not including harvest or overhead, to farm walnuts, $25 \%$ of this cost is in insect and disease control. Current pest management practices work well in most cases but environmental, human health, pests resistance, loss of pesticides, improved efficacy and regulatory concerns encourage the discovery and use of new pest control techniques.

${ }^{1}$ Pomology farm advisor, University of California Cooperative Extension, Butte County, 2279 Del Oro Avenue, Oroville, CA 95965

${ }^{2}$ Pomology farm advisor, University of California Cooperative Extension, Tehama County, 1754 Walnut Street, Red Bluff, CA 96080. 
The two most important insect pests of walnut are codling moth and walnut husk fly. A secondary, but sometimes important pest, is walnut aphid. The most important diseases of walnut include walnut blight, crown gall, and crown and root rot.

\section{Codling moth}

Codling moth is a major pest of walnut and all cultivars are susceptible to one degree or another. In general, early leafing cultivars are more prone to codling moth attack than late leafing cultivars. There are three to four generations of this moth each year in California. Codling moth larvae damage the kernel and most processors penalize crop deliveries that have $5 \%$ or greater total worm damage. Codling moth damaged nuts serve as a food bridge for navel orangeworm (Amyeloistransitella). Uncontrolled populations of codling moth could result in $40 \%$ worm damage from both species of worms. For more than 30 years generations were monitored with pheromone traps hung 5 to $6 \mathrm{ft}$ ( 1.5 to $1.8 \mathrm{~m}$ ) off the ground. A frequent application of azinphos-methyl (Guthion; Bayer Crop Protection, Kansas City, Mo.) or other toxic material applied when pheromone trap catches were high was the standard practice to control each generation.

A significant improvement in codling moth management occurred with the development of a phenology model. The model uses heat units or degreedays to predict seasonal moth development (Zalom and Wilson, 1982) and the accumulated product of time and temperature among the developmental thresholds for each day. A degree-day is $\mathrm{ld}(24 \mathrm{~h})$ with the temperature above the minimum developmental threshold by $1{ }^{\circ} \mathrm{F}\left(0.56^{\circ} \mathrm{C}\right)$. By measuring orchard temperatures, degree-days can be calculated, accumulated and used to predict codling moth activity. For walnut, growers start recording and accumulating degree-days when twilight air temperatures exceed $62^{\circ} \mathrm{F}\left(16.7^{\circ} \mathrm{C}\right)$ and moths are first consistently caught in traps. The average generation time for codling moth is 1060 degree-days (Pitcarin et al., 1992). First generation sprays are applied to coincide with egg hatch roughly 250 to 300 degree-days after the first biofix. Second generation treatments are made to coincide with egg hatch 200 to 250 degree-days after the second biofix. The process is repeated if a third generation spray is indicated. Pheromone trap data are used in combination with phenology models to verify moth activity and emergence events.

There are several new reduced risk methods becoming available to control codling moth. Reduced risk pesticides exhibit low mammalian toxicity and have minimal environmental impact (Van Steenwyk, 2000). Among the better-established reduced risk pesticides are the insect growth regulator materials tebufenozide (Confirm; Rhome and Haas, Philadelphia), diflubenzuron (Dimilin; Uniroyal Chemical, Middlebury, Conn.), and pyriproxyfen (Esteem; Valent Agricultural Products, Walnut Creek, Calif.). Tebufenozide, a larvacide, controls low to moderate populations of codling moth when applied properly. Diflubenzuron, an ovacide, must be combined with other conventional or reduced risk materials for best results. Pyriproxyfen, an ovicide, is very effective on scale insects but plays only a minor role in codling moth control.

Granulosis virus (Vail et al., 1980) and Bacillus thuringiensis (Pickel et al., 1998) are reduced risk materials sometimes used by organic growers and can be effective on low populations of $\mathrm{co}^{-}$ dling moth but require multiple applications of pesticide per generation.

Release of the parasitoid wasp, Trichogramma platneri, is another reduced risk codling moth control technique. Trichogramma platneri, indigenous to the western United States, is a tiny parasitic wasp that attacks, kills and completes its development inside the eggs of many Lepidoptera. Trichogramma platneri are raised on the eggs of stored product moths and are sold commercially as parasitized host eggs. The technique involves inundative releases of $T$. platneri timed to coincide with each biofix. Four releases are made per generation at weekly intervals during the egg laying period. Release rates are 200,000 parasitized host eggs per acre (494,200 eggs/ha). Parasitized host eggs are placed in the orchards either by aircraft or by hand application to allow emerging adult wasps to search for $\mathrm{CO}^{-}$ dling moth eggs for oviposition. Currently, inundative releases are not as effective as conventional insecticides (Mills et al., 2000) and are more expensive. This, combined with the challenges and logistics of handling large numbers of live eggs, limits commercial application.
Pheromone confusion, or mating disruption, is another reduced risk technique under investigation in California walnut orchards. Codling moth adults rely on chemical pheromones for males and females to find each other and mate. If sufficient pheromone is applied to walnut orchards it is possible to interfere with the mating/reproduction process. There are currently three methods of mass application of pheromone: hand applied, sprayables and aerosols. Hand applied ties and foils have pheromone incorporated into their structure and are typically hand placed into the upper one-third of the tree canopy. Foil dispensers such as $(\mathrm{E}, \mathrm{E})-8,10$-dodecadien1-01 (Checkmate X-1000; Suterra LLC, Bend, Ore.) and tie dispensers such as (E, E)-8,10-dodecadien-1-01 dodecanol (Isomate C Plus; Pacific Biocontrol Corp. Ridgefield, Wash.) are either clipped or twisted by hand onto branches at the, currently recommended, rate of 200 or 400 dispensers/acre (494 or 988 dispensers/ha), respectively. Although these devices evenly distribute pheromone, instillation is labor intensive particularly for orchards with large trees. One person in a pruning tower can treat about 5 acres ( 2 ha) with pheromone ties or foils $/ \mathrm{d}$. A single application of one brand of dispensers can give codling moth protection for the entire season. Current cost for labor and equipment is about $\$ 135 /$ acre (\$334/ha). New advances in aerial application may reduce labor cost.

Sprayable formulations are based on encapsulating small amounts of pheromone within tiny beads of synthetic polymers. Beads are applied using conventional orchard sprayers. Applications are made at 0.7 to $1.1 \mathrm{oz} / \mathrm{acre}$ (49 to $\left.74 \mathrm{~g} \cdot \mathrm{ha}^{-1}\right)$ and may need to be reapplied monthly. Current research efforts are aimed to refine these recommendations.

Aerosal delivery involves pressurized containers containing codling moth pheromone. The application devices (puffers) are set to deliver a predetermined number of puffs of pheromone per hour. Aerosal applicators are subject to mechanical failure and may not work well under windy conditions.

Preliminary pheromone confusion work in walnut looks promising (Welter et al., 2001), however researchers need a better understanding of how codling moth actually responds to pheromone inundation. Pheromone treatments are more expensive than conventional in- 
secticides and pheromone efficacy under heavy codling moth pressure is suspect, often requiring supplemental insecticide treatments.

New traps and lures for monitoring are becoming available. Synthetic rubber pheromone lures with longer field life are now available; lures with larger charges of pheromone are used in conjunction with mating disruption programs. Traps of different design and with larger sticky surfaces may be better in low populations because they catch more moths. Placing pheromone traps 15 to $20 \mathrm{ft}$ ( 4.6 to $6.1 \mathrm{~m}$ ) up into the tree canopy gives better resolution of moth activity in the orchard. A new kairomone lure that will attract both male and female moths (Light et al., 2000 ) is now commercially available.

\section{Walnut husk fly}

Walnut husk fly is a serious pest in mid to late-season walnut cultivars and in all growing areas of California except in parts of the central and southern San Joaquin Valley (Van Steenwyk and Barnett, 1998). Larval feeding in the husk causes shell staining and can lead to internal mold. Adult walnut husk flies emerge from the soil usually between July and September. There is one generation each year but pupae may remain in the soil for 2 years (Opp and Zermeno, 2000) creating significant adult fly population shifts from year to year in the same orchard. Walnut husk fly is monitored with a yellow sticky card. When trap catches increase, treatment is recommended. Several such trap catch increases may occur during the season. This system generally catches low numbers of flies and often results in treating before and more often than necessary. An improved trap monitoring system incorporates ammonium carbonate with the yellow sticky card to increase trap catch and the detection of gravid females. The date when eggs are first found in any of the female flies caught on the sticky traps serves as a biofix. This biofix indicates a treatment should be applied within a few days. This technique has greatly increased control by applying treatments closer to when they are needed and has cut down on the number of treatments needed. Pesticides are often applied in combination with a protein bait, which attracts the flies. This combination of materials allows for treating only alternate rows of trees with good success.

\section{Walnut aphid}

Aphid feeding can reduce tree vigor, nut size, yield and quality. Sooty mold growth on the honeydew excreted by the aphids blackens the walnut husk. This increases the chance of sunburn, which darkens or shrivels the kernels, on exposed nuts. Fifteen aphids/leaflet constitute an economic injury threshold and a treatment is recommended for populations reaching or exceeding this level. The introduced parasitic wasp, Trioxys pallidus, has reduced the need for chemical treatment of walnut aphid. Only a small percentage of orchards, mainly those in which predator populations have been disrupted by treatments for other pests, require treatment for walnut aphid (Bentley et al., 2000).

\section{Walnut blight}

Walnut blight is a very destructive bacterial disease of walnut particularly for early leafing cultivars in high rainfall locations. Warm, wet weather dramatically increases husk infection and kernel loss. Left untreated, damage can easily exceed $50 \%$ in a severe blight year. Copper compounds, applied prior to rainfall as a protectant, are the traditional treatment for walnut blight. Six or more sprays may be needed to protect the crop. Even a good copper spray program can result in 10\% crop loss. Copper tolerant bacteria are present in many California orchards and also affect copper efficacy. The addition of maneb (Manex; Griffin LLC, Valdosta Ga.) to traditional copper sprays, introduced in the early 1990s typically reduces damage by $50 \%$ compared to copper sprays alone (Buchner et al., 2001).

Another innovation for walnut blight management is the development, evaluation and utilization of the accumulation model for forecasting walnut blight (Adaskaveg et al., 2001). The model is a host phenology, temperature mediated, and wetness accumulation model called Xanthocast (University of California, Berkeley). Walnut growers can access the model at no cost and use it to make spray decisions based on indexes of disease infection risk. Infection risk plus rainfall probability are used to make spray decisions. The model is still under evaluation but is available for commercial use (FieldWise Inc., 2002).

\section{Crown gall}

Crown gall is wide spread in walnut culture in California. It is particu- larly dangerous when young trees are severely infected. Crown gall bacteria enter walnut tissue and alter host cells causing galls on the root system and crown of walnuts. Crown gall can severely stunt the growth of the tree and impact production. Very severe cases can kill young trees. Galls usually develop at or below the soil line and may remain undetected for several years, creating very large galls.

Paradox rootstock is highly susceptible to the bacteria disease crown gall (Olson and Buchner, 2001). However, because of its superior resistance to phytophthora crown and root rot, increased vigor and adaptability to marginal walnut soils the hybrid or paradox rootstock, which is a cross between english walnut and northern california black walnut (Juglans hindsii), is preferred by most California walnut growers.

Crown gall is best prevented by purchase of trees from a reputable nursery accompanied by careful handling to avoid injury, both during planting and during the life of the orchard (Teviotdale and Gubler, 2000). The biological control agent Agrobacterium radiobacter [(strain 84) Galltrol; AgBioChem Inc., Orinda, Calif.] is a preventative treatment and is used as a root dip prior to planting. It does not eradicate existing galls. Strains of $A$. tumefaciens, resistant to the biological control agent, have been reported (Teviotdale and Gubler, 2000).

Eradication of galls on existing trees involves extensive surgery and chemical treatment paying particular attention to removing the bark at the gall margin. This procedure may take 1 to $2 \mathrm{~h} /$ tree and, if done properly, is about $80 \%$ successful. An alternative faster, less expensive and equally effective method of eradicating galls from the crown area of trees was developed recently. A propane torch is used to isolate the gall by killing the tissue surrounding the gall with heat.

\section{Phytophthora crown and root rot}

Walnut tree roots, crowns and trunks are subject to infection by soilborne water mold fungi of the genus Phytophthora. The genus consist of about 70 species of some of the most devastating plant pathogens known (Mircetich et al., 1998). Extensive damage and death due to root and crown rot are usually associated with 
prolonged and repeated periods of water saturation of soil. This can result from excessive irrigation, rainfall, floods, or poor internal or surface drainage.

Eradication of Phytophthora species from soil is extremely difficult. Paradox rootstock is significantly more resistant to Phytophthora species than northern california black walnut or english walnut rootstocks and should be strongly considered where phytophthora crown and root rot may become a significant factor. Good soil and water management is most important. Planting on soils with good surface and internal drainage is highly recommended. The use of micro sprinklers and drip irrigation and irrigation scheduling devices help reduce the incidence of, irrigation influenced, outbreaks of crown and root rot. Irrigation water source is also a consideration since species of Phytophthora have been found in every surface source of water evaluated in California. These practices are the current leading edge recommendations to avoid phytophthora crown and root rot.

\section{Other insect and disease pest}

There are many other insect and disease pest of walnuts including navel orangeworm, twospotted spider mite (Tetranychus urticae), pacific spider mite (Tetranychus pacificus), walnut scale (Quadraspidiotusjuglansregiae), sanjose scale (Quadraspidiotus perniciosus), redhumped caterpillar (Schizura concinna), fall webworm (Hyphantria cunea,), walnut blackline virus, oak root fungus (Armillaria mellea), branch wilt (Hendersonula turuloidea), deep bark canker (Erwiniarubrifaciens), and shallow bark canker (Erwinia nigrifluens). Although research is underway to develop new approaches of combating many of these insect and disease pests, current standard recommendations can be found on the University of California's integrated pest management web site (Strand et al., 2001), in the publication Integrated Pest Management for Walnuts(Flint, 1993), or the Walnut Production Manual (Ramos, 1998).

The preceding leading edge and other new tools used to combat insect and disease pests in walnut production hold great promise in reducing the amount of pesticides used, improving on pesticide application timing and mitigating the many concerns over the use of pesticides in walnut production.

\section{Literature cited}

Adaskaveg, J., H. Förster, J. DieguezUribeondo, D. Thompson, C. Adams, C. Thomas, R. Buchner, and W. Olson. 2001. Epidemiology and management of walnut blight, p. 329-357. In: Walnut research reports 2001. Calif. Walnut Mktg. Board, Sacramento.

Bentley, W.J., W.W. Coates, J. Hasey, L.C. Hendricks, W.H. Olson, C. Pickel, G.S. Sibbett, and R.A. Van Steenwyk. 2000. UC IPM pest management guidelines, insects and mites: Walnut. IPM Educ. and Publ., Univ. Calif. Statewide Integrated Pest Mgt. Proj.

Buchner, R.P., W.H. Olson, J.E. Adaskaveg, and S.E. Lindow. 2001. Walnut blight (Xanthomonas campestris pv. juglandis) control investigations in northern California, USA. Acta Hort. 544:369378.

FieldWise, Inc. 2002. Walnut blight risk map. 19 June 2002. <http://www.fieldwise.com./registered/data/wbmap/ xanthfrcst.shtml>.

Flint, M.L. (ed.). 1993. Integrated pest management for walnuts. $2^{\text {nd }}$ ed. Univ. Calif. Statewide Integrated Pest Mgt. Proj., Div. Agr. Natural Resources, Publ. 3270.

Light, D., K. Reynolds, J. Grant, J. Groh, C. Pickel, N. Darby, T. Prichard, M. Rego, J. Hasey, W. Bentley, B. Ribeiro, R. Buchner, B. Olson, A. Knight, S. Lingren, and B. Campbell. 2001. Advances in development of a monitoring and management system for codling moths based on a novel female and male attractant kairomone, p. 207-241. In: Walnut research reports 2001. Calif. Walnut Mktg. Board, Sacramento.

Mills, N., C. Pickel, S. Mansfield, S. McDougall, R. Buchner, J. Caprile, J, Edstrom, R. Elkins, J. Hasey, K. Kelley, B. Krueger, B. Olson, and R. Stocker, 2000. Mass releases of Trichogramma wasps can reduce damage from codling moth. Calif. Agr. 54(6):22-25.

Mircetich, S.M.J., G.T. Browne, M.E. Matheron, and B. L. Teviotdale 1998. Armillaria and Phytophthora root and crown rot diseases, p. 221-232. In D.D. Ramos (ed.), Walnut production manual. Univ. Calif., Div. Agr. Natural Resources, Publ. 3373.

Olson, B. and R. Buchner, 2001. Field treatment of crown gall in walnut. Pacific Nut Producer 7(7):8-30.
Opp, S., and J. Zermeno. 2000. Timing and susceptibility of walnut cultivars to walnut husk fly attack-episode 2, p. 293 295. In: Walnut research reports 2000. Calif. Walnut Mktg. Board, Sacramento.

Pickel, C., W. Bentley, N. Mills, W. Olson, R. Buchner, N. Darby, and L. Martin. 1998. Investigations of long-term codling moth management in walnuts, p. 159168. Walnut Research Reports 1998. California Walnut Marketing Board, Sacramento.

Pitcarin, M.J., F.G. Zalom and R.E. Rice, 1992. Degree-day forecasting of generation time of Cydia pomonella (Lepidoptera: Tortricidae) populations in California. Environ. Entomol. 21:441-446.

Ramos, D.E. (ed.). 1998. Walnut production manual. Univ. Calif., Div. Agr. Natural Resources, Publ. 3373.

Strand, J.F., B. Dreyer, and K. Garvey. 2001. UC pest management guidelines: Pests of walnut. 19 June 2002. <http:// www.ipm.ucdavis.edu/PMG/selectnewpest.walnuts.html>

Teviotdale, B.L. and W.D. Gubler, 2000. UC IPM pest management guidelines, diseases: Walnut. IPM Educ. Publ., Univ. Calif. Statewide Integrated Pest Mgt. Proj.

Tippett, J., D. Nelson, G. Nelson, D. Flohr, and J. Van Court, 2001.2001 California walnut objective measurement survey report. Calif. Agr. Stat. Serv., Sacramento.

Vail, P., G.S. Sibbett, and W.W. Barnett, 1980. Granulosis virus for control of codling moth in walnuts. p.10. Abstracts of Walnut Research Progress 1980. Walnut Marketing Board, San Francisco.

Van Steenwyk, R. 2000. Reduced risk insecticides and their use in walnut pest management, p. 251-256. Walnut Research Reports 2000. Calif. Walnut Mktg. Board, Sacramento.

Van Steenwyk, R.A. and W.W. Barnett. 1998. Insect and mite pests, p. 247-253. In D.D. Ramos (ed.). Walnut production manual. Univ. Calif., Div. Agr. Natural Resources Publ. 3373.

Welter, S.C., F. Cave, and M. Singleton. 2001. Development of alternative pheromone dispensing technologies for management of codling moth, p. 165-205. Walnut research reports, 2001. Calif. Walnut Mktg. Board, Sacramento.

Zalom, F. and T. Wilson. 1982. Degreedays in relation to an integrated pest management program. Univ. Calif. Div. Agr. Sci. Lflt. 21301. 